\title{
E. B. EN V. B. IN ONZE INDIËN
}

DOOR

W. D. H. BARON VAN ASBECK.

In het Handelsblad van Dinsdag 30 October 1917 plaatste een nieuw gevormde Economische Bond een „Op roep aan eensdenkenden" waarin de volgende Koloniale paragrafen voorkwamen:

4. Nauwere aaneensluiting van Moederland en Koloniën zonder prijsgeving van het beginsel der „open deur” politiek.

27. Bestiering en ontwikkeling van Nederlandsch Oost-Indië, Suriname en Curaçao als zelfstandige rechtsgemeenschappen in den Nederlandschen Staat; geestelijke, staatkundige en economische opvoeding van de inheemsche bevolkingsgroepen naar hun behoeften en belangen, met hun medewerking en met eerbiediging en gebruikmaking zooveel mogelijk van hun instellingen. Krachtige bevordering van de intellectueele ontwikkeling van de bevolking in de Nederlandsche Koloniën en bevordering van het Technisch Onderwijs aldaar. Bevordering der ontginning van de natuurlijke hulpbronnen der Koloniën, in het belang zoowel van de inheemsche bevolking als van het moederland.

Het staatsprogram van den Vrijheidsbond, door fusie met derden uit den Economischen bond gegenereerd, bevat de volgende koloniale paragraaf:

10. Bevordering van het Zelfbestuur in Oost- en West-Indië onder handhaving van de saamhoorigheid met het Rijk in Europa.

Verheffing van het geestelijk en maatschappelijk peil der inheemsche bevolking.

Ontwikkeling van de koloniale hulpbronnen inzonderheid ten behoeve van Indië-zelf. 
Het program van actie van den Vrijheidsbond zet de volgende lijnen uit:

20. Geleidelijke invoering onder Nederlandsch oppergezag van autonomie en zelfbestuur in Indië voor zoover de daartoe noodige krachten in de samenleving aldaar bestaan of opkomen.

Ontwikkeling van den Volksraad in de richting van eene vertegenwoordiging van de verschillende bestanddeelen van de Indische samenleving.

21. Ontwikkeling op geestelijk, technisch, maatschappelijk en economisch gebied van alle bevolkingsgroepen met inachtneming van hetgeen door den natuurlijken groei in de behoeften van die groepen wordt gevorderd.

22. Aanmoediging van het particuliere bedrijfsleven als noodzakelijke factor van Indië's ontwikkeling; zoo groot mogelijke vrijheid van beweging daarvan met niet verder gaande Staatsbemoeienis dan het belang van de gemeenschap eischt.

Krachtige ontwikkeling van Indië's hulpbronnen; bevordering van de toestrooming van energie en kapitaal van buiten als onmisbaar voor den economischen vooruitgang.

23. Herstel van het evenwicht in de Indische finantiën, daarbij voldoende rekening houdende met de draagkracht der Indische samenleving en hare behoefte aan kapitaalvorming.

Wie deze stukken vergelijkt komt al dadelijk tot de slotsom dat West-Indië hoe langer hoe mee op den achtergrond, ja eindelijk geheel weg is geraakt.

In den „oproep" van de oprichters van den E. B. werden de West-Indische koloniën met name en terecht Zelfstandige Rechtsgemeenschappen in den Nederlandschen staat genoemd; daarna werd er gesproken van de bevordering der intellectueele ontwikkeling van de bevolking der Nederlandsche koloniën en der ontginning van de natuurlijke hulpbronnen der Nederlandsche koloniën; in beide laatste termen werden Oost- en West-Indië over één kam geschoren.

In het staatsprogram van den $\mathrm{V}$. B. vinden wij van dit alles niet meer dan een flauwen weerklank. De juiste, rechtmatige en zoo veel perspectief biedende qualificatie van, Zelfstandige Rechtsgemeenschappen”, die zoo duidelijk de Oost- en West-Indische gebiedsdeelen op één lijn 
stelt met het moederland, is verdwenen. Bij de bevordering van het zelfbestuur is nog even van West-Indië sprake. Maar bij de ontwikkeling van de Koloniale hulpbronnen wordt er alleen aan Indië d.i. Nederlandsch (Oost) Indië gedacht. Er wordt echter één nieuw geluid vernomen. De saamhorigheid: een krachtiger term dan de „nauwere aaneensluiting van Moederland en Koloniën”, waarvan de „Oproep” gewaagde. Wij danken dien term aan van Deventer, uit wiens geschriften hij overgenomen werd in de Troonrede van 1913. Maar èn van Deventer èn de Troonrede spraken van saamhoorigheid „van Moederland en Koloniën en van al de bewoners dezer gebiedsdeelen"; het staatsprogram verkort de strekking door de al-saamhoorigheid te laten glippen en niet verder te zien dan saamhoorigheid van de Koloniën met het Rijk in Europa; niet onderling.

En nu het program van actie van den Vrijheidsbond: W e s t-I ndi ë, i k groet U. Uit.

Indien de Oost-Indische punten van actie en de WestIndische vraagstukken volkomen ongelijksoortig waren en deze laatste dus tot groote uitbreiding van het program moesten leiden, zoude men het doodzwijgen van West-Indië daarmede hebben kunnen vergoelijken. Maar er zijn verscheiden punten in de koloniale paragrafen, die mutatis mutandis voor West-Indië niet anders zouden luiden dan voor Oost-Indië.

Voor Indië wordt ,,autonomie en zelfbestuur” genoemd (20); Suriname en Curaçao hebben geen zelfbestuur. Ontwikkeling van alle bevolkingsgroepen wordt voor Indië gevraagd (21); hebben Suriname en Curaçao geen bevolkingsgroepen? Suriname kan er, met uitsluiting van de blanken, al dadelijk vier aanwijzen: Indianen, Creolen (negers en kleurlingen), Britsch-Indiërs en Nederlandsch-Indiërs. Aanmoediging van het particuliere bedrijfsleven (22) heet voor Indië een noodzakelijke factor van ontwikkeling; geef den van veldarbeid afkeerigen neger bedrijfsarbeid, waarvoor hij de noodige intelligentie ten volle bezit en hij werkt mede aan de ontwikkeling van zijn geboorteland,dat allereerst handen te kort komt. 
En slaat de tweede zin van paragraaf (22): „Krachtige ontwikkeling van Indië's hulpbronnen, bevordering van de toestrooming van energie en kapitaal van buiten als onmisbaar voor den economischen vooruitgang" den West-Indischen spijker niet op den kop? Paragraaf (23) doet dit niet minder: „Herstel van het evenwicht in de Indische finantiën". Alleen kan er t. a. v. Suriname geen sprake zijn van „herstel”. Dáár is nooit evenwicht geweest; wel eens in Curaçao. Is nu den steller van het program van actie en hun, die het goedkeurden, alles. voorbijgegaan wat de laatste ja en ten behoeve van schepping van evenwicht in de Surinaamsche finantiën is gedacht, gezegd en gedaan? Liggen de rapporten van Bos c.s. (welvaartcommissie) en van het Suriname-studie-syndicaat al in zijn prullemand?

Ten slotte eene opmerking, die oproep en staatsprogram geldt.

De oproep sprak van ,inheemsche bevolkingsgroepen” en van ,inheemsche bevolking” en stelde, vreemd genoeg, niet de kolonie naast het moederland, maar hare inheemsche bevolking, alsof eenheid van land en volk, juist waar dit zoo heterogeen van samenstel is, ooit sterk genoeg kan worden uitgedrukt; en ook het staatsprogram spreekt van ,inheemsche bevolking”. Het program van actie kent de tegenstelling tusschen „,inheemsche” en „niet-inheemsche" bevolking niet

Kan eene bevolking niet-inheemsch zijn? Het schijnt zoo. Onder niet-inheemsche bevolking zal men dan moeten verstaan geïmmigreerden. Zoo ja, worden dan uitsluitend blanke immigranten en hun telgen als niet-inheemsch beschouwd? Aangenomen dat dit zoo is, waarom werden die dan door E. B. uitgesloten van geestelijke, staatkundige en economische opvoeding (oproep), van het genot der vruchten van de ontginning van den bodem (oproep), door henzelf veelal geleid; of waarom thans nog door den V.B. van verheffing van het geestelijke en maatschappelijk peil (staatsprogram)? Hebben de blanken in de Koloniën het culminatiepunt al bereikt? Dan ziet het er treurig uit. 
Maar nemen wij aan dat met „niet-inheemschen” alle immigranten bedoeld worden; dat met ,inheemschen" alleen bedoeld wordt de oorspronkelijke bevolking. Dan worden aan de door het Staatsprogram gestelde verheffing van het geestelijk en maatschappelijk peil onttrokken de geheele bevolking van Curaçao en op \pm 1500 Indianen na de geheele bevolking van Suriname.

Het program van actie is op dit punt verstandig geweest. Het spreekt van ,,alle bevolkingsgroepen"; van de Indische „samenleving”; en van ,bestanddeelen der Indische samenleving” waarin „Indische” door „Koloniale" dient vervangen. De moeder spiegele zich aan haar kind. Onder inheemschen alleen de oorspronkelijke bewoners te verstaan leidt tot dwaasheid. Onder niet-inheemschen alleen blanken te verstaan doet niet anders. Hoe dan de grens te trekken? Beter is het van elke begrenzing af te zien. 